\title{
Family Resilience in ADHD Child Parenting
}

\author{
$1^{\text {st }}$ Ika Candra Destiyanti \\ Universitas Islam Al Ihya Kuningan \\ Kuningan, Indonesia \\ ikacandradestiyanti@gmail.com
}

\begin{abstract}
Family resilience is influenced by aspects of managing the problem and its resources so that a prosperous family is formed. Handling problems in families with child care indicated by ADHD will be different from each other in view of the diversity of the gods they experience. (Attention Deficit Hyperactivity Disorder) research methods using qualitative phenomenology. The results of his research are that children with ADHD need to be accompanied by a therapist in their handling, doing a lot of meaningful activities with the family such as listening to stories to finish, until it is possible to do a cultural diet for motor activities. Good family endurance will reduce the indications of ADHD disorders in children.
\end{abstract}

Keywords-Hyperactivity Gangguan Perkembangan, Terapi Keluarga, Motor Activities George F

\section{INTRODUCTION}

ADHD or Attention Deficit and Hyperactivity Disorder is a disorder of concentration and hyperactivity. International studies cite prevalence rates ranging from $5 \%$ to $7 \%$ in the school-age population [1]. That is, in a child with ADHD, there is a developmental disorder in increasing motor activity that causes unusual or excessive activity. There are also those who call ADHD behavior disorder, based on the number of movements produced without knowing the place and purpose or rising emotions (impulsivity). [2]. Proper family parenting will reduce the level of impulsivity.

Attention Deficit/Hyperactivity Disorder including developmental disorders with a prevalence of $6-9 \% \quad[3,4]$ attacking children with irritability cannot sit quietly easily with children who attack children $[5,6]$.

While current treatments improve ADHD symptoms in some children [7], symptoms often continue into adulthood. ADHD in children generally indicates poor long-term outcomes, including lower educational and work performance, unstable relationships, detention, and ongoing psychiatric problems [8-10]. Pharmacological effects are associated with side effects, and possible long-term health risks [11]. a trend toward research [12], nutrition-based care.

Pharmacological and non-pharmacological interventions can help reduce the symptoms of ADHD, but some sufferers of ADHD functional disorders that negatively affect life with family [13]. Results of the study say $30 \%$ of children / adolescents with ADHD fail to treat medication with a single stimulant and $10 \%$ do not respond any stimulant [14]

In children with ADHD disorders, irregular emotions are characteristics that are easily recognized as an indication of the disorder [15]. Generally, parents who have children with ADHD disorders only realize after primary school age that ADHD children will have difficulty focusing attention and listening to the direction of their instructors. this behavior will affect student achievement. Without proper treatment, ADHD can have serious consequences such as underachievement, failure at school or work, difficult relationships or social interactions, severe insecurity, and also chronic depression [16].

\section{METHOD}

The research method uses qualitative with inductive analysis. Where the research process of the hypothesis of some theories about ADHD De Clerq's theory based on its terminology, divided into 2 groups.

First with the terms "Minimal Brain Damage" and "Minimal Brain Disfunction", reflecting ideas about assumptions about the causes of the disorder, and second, with terms such as "Hyperkinetic Reactions of Childhood", "Hyperkinetic Child Syndrome", and "Attention Deficit Hyperactivity Disorder" According to De Clerq, there are several historical developments in the emergence of ADHD, including: 1. In 1930 to 1960, this disorder was known by the public with the term Minimal Brain Damage.

This term refers to brain damage. The explanation, some children with problems of hyperactivity, attention, and concentration show brain injury through an abnormal inability to focus attention, anxiety, and anxiety ". [17] based on the theoretical characteristics of some figures regarding children with ADHD disorders, in-depth research was conducted on 10 families who have children with ADHD disorders aged 2 to 12 years.

Respondents were children who had ADHD disorders with 7 children who had obtained medical attention and 3 who did not receive medical treatment. Furthermore, the authors conducted data analysis using the triangulation method, namely, surveys, interviews and medalam observations. At the survey stage, 10 respondents from provinces in Indonesia were determined to have children with ADHD disorders and then conducted interviews with families with children with ADHD disorders and did direct observations to children with ADHD disorders, including how families deal with children with ADHD disorders.

The data taken is then drawn conclusions of the characteristics that occur in the community of children with ADHD disorders with the characteristics of the opinions expressed by the opinion that states children with ADHD disorders.

\section{RESULT}

A. Expert Opinions about the characteristics of ADHD Children

1. According to Russell Barkley ADHD is a hallmark 
a. Not able to withstand interference: pay less attention b. Not able to control thinking: Impulsive c. Not able to control actions such as interference or Hyperactive thoughts. 2. According to Lovecky described ADHD as a disorder that can be detected before a 7-year-old child, but in practice many people do not diagnose this until they grow older. ADHD is divided into 3 subtypes: predominant type of inattention, hyperactive / impulsive predominant type, and combination type characterized by lack of attention and highlevel hyperactivity-impulsivity

3. According to Ferdinant, ADHD disorder is a child with various limitations and has behavioral, social, cognitive, academic, and emotional problems, and experiences obstacles in actualizing his intelligence potential. From the characteristics stated by the authors explore through inductive qualitative research in which 10 respondents with various backgrounds and analyzed through interviews and direct observation obtained the following data:

TABLE 1. FEATURE OF A CHILD

\begin{tabular}{|c|c|c|}
\hline Hyperactive & Impulsive & Intense \\
\hline $\begin{array}{c}\text { Could not sit } \\
\text { quietly. }\end{array}$ & Strong-willed. & $\begin{array}{c}\text { Not meticulous or } \\
\text { careless }\end{array}$ \\
\hline $\begin{array}{c}\text { Running or } \\
\text { a purpose and a } \\
\text { clear reason and } \\
\text { not in place }\end{array}$ & $\begin{array}{c}\text { Problem with } \\
\text { regulation or rules }\end{array}$ & $\begin{array}{c}\text { Often miss or lose } \\
\text { things. }\end{array}$ \\
\hline $\begin{array}{c}\text { Always moving } \\
\text { wherever and } \\
\text { whenever. }\end{array}$ & $\begin{array}{c}\text { Trouble with } \\
\text { delaying the turn } \\
\text { (waiting in line) }\end{array}$ & $\begin{array}{c}\text { Does not like tasks } \\
\text { related to high } \\
\text { concentration }\end{array}$ \\
\hline Fussy & $\begin{array}{c}\text { Impatient. } \\
\text { Often interrupting } \\
\text { other people's } \\
\text { conversation }\end{array}$ & $\begin{array}{c}\text { Does not like tasks } \\
\text { related to high } \\
\text { concentration } \\
\text { - }\end{array}$ \\
\hline $\begin{array}{c}\text { Act without } \\
\text { thingking about } \\
\text { the risks and } \\
\text { effects that will } \\
\text { befall him or } \\
\text { others. For } \\
\text { example, hitting } \\
\text { or kicking just } \\
\text { because of a small } \\
\text { problem }\end{array}$ & $\begin{array}{c}\text { Lack of eye contact } \\
\text { (not staring at } \\
\text { interlocutors) }\end{array}$ \\
\hline
\end{tabular}

In table 1 this study the results obtained that 7 families who have received medical treatment and therapy according to the advice of their medical team from adapted advice for children ADHD have a tendency to decrease the level of hyperactivity and its level of regulation. Some children who get behavioral therapy, food diet or occupational therapy can control themselves in the classroom during lessons. Can focus attention within 30 minutes on the teacher's lecture in the classroom. Hyperactivity, Impulsiveness and intensity characteristics are reduced when the family implements the therapeutic discipline for children with ADHD disorders while for families without medical attention the intensity of attention disorders often occurs when the child is positioned uncomfortable.
The case of family $\mathrm{G}$ who has ADHD disorder children who do not get therapy and medical care in foster care with family resilience without medical resources has a high risk in care. 3 times a week children with ADHD go away from home and run to the beach. Parents with ADHD child care without the proper knowledge of treatment for children with ADHD indicated that they experienced difficulties in their care patterns. The case of family $\mathrm{G}$ with family resources of 4 children earning as a religious teacher while the mother of the household wife must face a child with ADHD disorder has many obstacles namely improper handling in calming children with high hyperactivity levels which actually triggers children with ADHD disorders to leave House. Inadequate feeding of children in ADHD will trigger the activity of children with high ADHD. Some of the therapies below are therapists in families who do therapy to overcome ADHD. 1. Occupational Therapy. Namely, Occupational Therapy Games or OTG is a therapy that focuses on sensomotor, cognitive and neurological processes (nerves) so that children can process, complete and treat their environment in such a way. 3 families with therapist support doing therapeutic activities at home is.

\begin{tabular}{|c|c|c|}
\hline$\frac{\text { Nama }}{\text { Kegiatan }}$ & Aktivitas & Fungsi \\
\hline Activity of 1 & $\begin{array}{l}\text { Jumping frog while } \\
\text { counting. }\end{array}$ & $\begin{array}{l}\text { Train motor } \\
\text { sensors }\end{array}$ \\
\hline Activity of 2 & $\begin{array}{c}\text { Slide (after completing } \\
\text { The Challenge) }\end{array}$ & $\begin{array}{c}\text { Reducing } \\
\text { Impulsiveness }\end{array}$ \\
\hline Activity of 3 & $\begin{array}{l}\text { Playing lotion to } \\
\text { provide tactile sensor } \\
\text { stimulus (tactile) by } \\
\text { applying lotion to the } \\
\text { glass and drawing } \\
\text { according to the } \\
\text { therapist's } \\
\text { instructions. }\end{array}$ & $\begin{array}{ll}\text { Reducing } & \text { the } \\
\text { activity } & \text { of } \\
\text { moving } & \\
\text { aimlessly } & \\
\text { (reducing } & \\
\text { impulsivity) } & \end{array}$ \\
\hline Activity of 4 & $\begin{array}{l}\text { Bear hugs for } \\
\text { example children are } \\
\text { swaddled with thick } \\
\text { blankets and asked to } \\
\text { roll. }\end{array}$ & $\begin{array}{l}\text { Reducing the } \\
\text { impulse to want } \\
\text { to follow the } \\
\text { rules }\end{array}$ \\
\hline Activity of 5 & $\begin{array}{l}\text { Pursue on the balance } \\
\text { board. }\end{array}$ & $\begin{array}{l}\text { Reducing the } \\
\text { impulse to want } \\
\text { to follow the } \\
\text { rules }\end{array}$ \\
\hline Activity of 6 & Play Flying fox & $\begin{array}{l}\text { Reducing the } \\
\text { impulse to want } \\
\text { to follow the } \\
\text { rules }\end{array}$ \\
\hline Activity of 7 & $\begin{array}{l}\text { Activate in the ball } \\
\text { pool }\end{array}$ & $\begin{array}{l}\text { Reducing the } \\
\text { impulse to want } \\
\text { to follow the } \\
\text { rules }\end{array}$ \\
\hline
\end{tabular}

3. Speech Therapy has a function to train ADHD children to decrease attention disorders. 
TABLE 3 ACTIVITIES OF SPEECH THERAPY

\begin{tabular}{|c|c|}
\hline Name of activity & \multicolumn{1}{|c|}{ Activity } \\
\hline Activity of 1 & \multicolumn{1}{|c|}{ Use a flash card } \\
\hline Activity of 2 & $\begin{array}{l}\text { Give orders or talk to children } \\
\text { that children do not have trouble } \\
\text { managing orders. }\end{array}$ \\
\hline Activity of 3 & Wait until the child finishes talking. \\
\hline Activity of 4 & $\begin{array}{c}\text { Pronounce words clearly, slowly } \\
\text { and consistently }\end{array}$ \\
\hline
\end{tabular}

Therapy carried out by 7 children who have ADHD who have been diagnosed and given treatment by the therapist experienced significant changes ranging from adding vocabulary, willing to obey the rules, not playing according to his wishes to be more focused with his opponent. However, for 3 children who did not receive therapeutic treatment and were treated with the same treatment as other normal children, they had problems with the rules, could not concentrate for a long time and could not limit their activities even though their body was tired, this was dangerous for children who had ADHD disorders because the body was there time for a break.

\section{CONCLUSION}

The results of his research are that children with ADHD need to be accompanied by a therapist in their handling, doing a lot of meaningful activities with the family such as listening to stories to finish, until it is possible to do a cultural diet for motor activities. Good family endurance will reduce the indications of ADHD disorders in children.

Therapy carried out by 7 children who have ADHD who have been diagnosed and given treatment by the therapist experienced significant changes ranging from adding vocabulary, willing to obey the rules, not playing according to his wishes to be more focused with his opponent. However, for 3 children who did not receive therapeutic treatment and were treated with the same treatment as other normal children, they had problems with the rules, could not concentrate for a long time and could not limit their activities even though their body was tired, this was dangerous for children who had ADHD disorders because the body was there time for a break.

\section{REFERENCES}

[1] Polanczyk, G. V., Willcutt, E. G., Salum, G. A., Kieling, C., \& Rohde, L. A. (2014). ADHD prevalence estimates across three decades: An updated systematic review and meta-regression analysis. International Journal of Epidemiology, 43, 434---442. http://dx.doi.org/10.1093/ije/dyt261

[2] American Psychiatric Association, Diagnostic and Statistical Manual of Mental Disorders, fourth ed., American Psychiatric Association, Washington, DC, 1994

[3] M.L. Danielson, R.H. Bitsko, R.M. Ghandour, J.R. Holbrook, M.D Kogan, S. J. Blumberg, Prevalence of parent-reported ADHD diagnosis and associated treatment among U.S. Children and adolescents, 2016 , J. Clin. Child Adolesc. Psychol. 47 (2) (2018) 199-212.
[4] F. Lenzi, S. Cortese, J. Harris, G. Masi, Pharmacotherapy of emotional dysregulation in adults with ADHD: a systematic review and metaanalysis, Neurosci. Biobehav. Rev. (2017).

[5] D.P. Dickstein, Mechanisms distinguishing irritability in children and adolescents, Am. J. Psychiatr. 173 (2016) 653-654.

[6] R.A. Barkley (Ed.), Attention-Deficit Hyperactivity Disorder: A Handbook for Diagnosis and Treatment, third ed., The Guilford Press, New York, NY, 2006

[7] R.G. Klein, S. Mannuzza, R. OMA, E. Roizen, J.A. Hutchison, E.C. Lashau, X. Castellanos, Clinical and functional outcome of childhood attention-deficit/ hyperactivity disorder 33 years later, Arch. Gen. Psychiatr. (2012) 1-9.

[8] S. Mannuzza, R.G. Klein, A. Bessler, P. Malloy, M. LaPadula, Adult outcome of hyperactive boys - educational achievement, occupational rank, and psychiatric status, Arch. Gen. Psychiatr. 50 (1993) 565-576.

[9] B.S.G. Molina, S.P. Hinshaw, J.M. Swanson, L.E. Arnold, B. Vitiello, P.S. Jensen, e al, The MTA at 8 Years: prospective follow-up of children treated for combined-type ADHD in a multisite study, J. Am. Acad. Child Adolesc. Psychiatry 48 (5) (2009) 484-500.

[10] A. Baumgaertel, Alternative and controversial treatments for attentiondeficit/ hyperactivity disorder, Pediatr. Clin. N. Am. 46 (5) (1999) $977-$ 992

[11] E.J. Sonuga-Barke, D. Brandeis, S. Cortese, D. Daley, M. Ferrin, M. Holtmann, J. Stevenson, M. Danckaerts, S. Van der Oord, M. D€opfner, Nonpharmacological interventions for ADHD: systematic review and meta-analyses of randomized controlled trials of dietary and psychological treatments, Am. J. Psychiatry 170 (3) (2013) 275289

[12] J. Nigg, K. Lewis, T. Edinger, M. Falk, Metaanalysis of attentiondeficit/ hyperactivity disorder or attention-deficit/hyperactivity disorder symptoms, restriction diet, and synthetic food color additives, J. Am. Acad. Child Adolesc. Psychiatry 51 (1) (2012) 86-97 e88.

[13] Preuss, U., Ralston, S.J Balddursson, G., Falissard, B.,Lorenzo,M.J., Rodriguess,P.R., L.,Coghill,D.,2006. Study design, baseline patient characteristics and interventionona cross culture framework:result from the ADORE study. Eur.Child Adolesc.Psychiatry 15(Supp11), 14-114

[14] Arnold,L.E.,2000.Methylphenidatevs.amphetamine: comparativereview.J.Atten.Disord3,200-211

[15] F. Lenzi, S. Cortese, J. Harris, G. Masi, Pharmacotherapy of emotional dysregulation in adults with ADHD: a systematic review and metaanalysis, Neurosci. Biobehav. Rev. (2017).

[16] D.P. Dickstein, Mechanisms distinguishing irritability in children and adolescents, Am. J. Psychiatr. 173 (2016) 653-654.

[17] http://repository.ump.ac.id/3860/3/Purna\%20Nanda\%20Suga ri\%20BAB\%20II.pdf 